Crime, Histoire \& Sociétés / Crime, History \& Societies

Vol. 2, n² | 1998

Histoire de la criminalité et de la justice pénale en Amérique latine / Criminal justice history in Latin America

The sovereign's vigilant eye ? Daily policing and women in Rio de Janeiro, 1907-1930

Marcos Luiz Bretas

OpenEdition

Journals

Electronic version

URL: https://journals.openedition.org/chs/966

DOI: $10.4000 /$ chs. 966

ISSN: 1663-4837

Publisher

Librairie Droz

Printed version

Date of publication: 1 June 1998

Number of pages: $55-71$

ISBN: 2-600-00311-8

ISSN: $1422-0857$

Electronic reference

Marcos Luiz Bretas, "The sovereign's vigilant eye? Daily policing and women in Rio de Janeiro,

1907-1930", Crime, Histoire \& Sociétés / Crime, History \& Societies [Online], Vol. 2, n² | 1998, Online since 03 April 2009, connection on 22 March 2022. URL: http://journals.openedition.org/chs/966 ; DOI:

https://doi.org/10.4000/chs.966 


\title{
The sovereign's vigilant eye? Daily policing and women in Rio de Janeiro, 1907-1930
}

\author{
Marcos Luiz Bretas'
}

"Remember all the time that the sovereign's vigilant and active eye is always ready to reward those who satisfy his fatherly views, and to punish those who do not concur to so commendable ends."

Royal Charter creating the Royal Military Academy, $1810^{2}$

The article discusses the role of the police in early twentieth-century Rio de Janeiro, focusing on the control of female behaviour in the records of police stations. The study of police attitudes towards women provides a useful introduction to a more general analysis of how policemen develop their world-views and behaviour. Contrary to common assumptions, women were frequently present in daily police work, either as criminals or victims, and policemen tried to select those deserving of protection, and those who should be seen as a threat to morality or order. This close relationship enables us to analyse how policemen developed their views about society and morals, observing the procedures they established for dealing with female thieves, vagrants, prostitutes, and victims of sexual offences.

Cet article traite du rôle de la police de Rio de Janeiro au début du XX $X^{e}$ siècle, et en particulier sur le contrôle du comportement féminin, tel que les archives policières le restituent. Étudier les attitudes policières envers les femmes débouche sur l'analyse plus générale de la version du monde et de la conduite des policiers. Contrairement à une croyance répandue, les femmes étaient fréquemment présentes comme criminelles ou victimes dans le travail quotidien des policiers et ces derniers tentaient de distinguer celles qui méritaient protection de celles qui constituaient, à leurs yeux, une menace à la moralité ou à l'ordre. Cette relation étroite nous permet d'analyser le développement des perceptions policières de la société et des mours en observant quelles procédures furent mises en place pour traiter les voleuses, les vagabondes, les prostituées et les victimes d'atteintes sexuelles.

1 Marcos Luiz Bretas is Professor of History at the Department of History, Universidade Federal do Rio de Janeiro, Brazil. He has recently published A Guerra das Ruas. Povo e polícia na cidade do Rio de Janeiro, 1889-1907 (Rio de Janeiro, Arquivo Nacional, 1997) and Ordem na Cidade. $O$ exercício cotidiano da autoridade policial no Rio de Janeiro: 1907-1930 (Rio de Janeiro, Rocco, 1997). His current interests include the role of the military police in nineteenth-century Brazil, and the organisation of political policing during the democratic period 1945-1964.

Paper presented to the international colloquium «Historia del Delito y la Justicia en America Latina», Buenos Aires, 17-19 October 1996.

Quoted by Câmara (1985, p. 12). 
The subject of policing in Latin America has appeared very recently in historiography. Though the matter of public order was not considered irrelevant, it was perceived as a small and unproblematic part of the activities of the state, especially, of the authoritarian state. Moreover, trying to access the available sources presented serious problems, making the practice of history a risky business. Only the general process of re-democratisation in the 1980 s allowed researchers to look into those sources, while at the same time stressing the unavoidable importance of the matter when discussing the prospects of Latin American democracy.

Latin America was the chosen hideout for nine out of ten Hollywood criminals. There, they could find a corrupt - and violent - police-force, ready, for a price, to allow these criminals to enjoy the profits of their illegal activities. The tribute they expected to pay was not high, for justice south of the Rio Grande was considered very cheap. The themes of crime and justice were not unknown to the cultural or political history of Latin America but, since criminal justice was only a small part of a very corrupt state structure, its study was not deemed necessary or important.

In the case of Brazil (and this is probably the same for other countries of the Southern Cone), it was the violence of military rule, directed against people of all social classes, that exposed the violent and corrupt practices of policing, raising questions about how it worked. Military dictatorship provided two easy explanations for the police model: it placed the blame of police violence on the recent developments and assumed the existence of an extremely powerful state, with a very efficient police surveillance system, controlling and repressing the efforts of civil society to liberate itself from undesired tyranny. Thus, the first efforts in the history of policing in Latin America presented the police as the long arm of the state, always ready to repress strikes or any other claims against the ruling elites. This is still the most important trend, and it has a considerable theoretical appeal for scholars. It reinforce, not the role of the police - which was in fact quite important - , but its capacity to provide a reliable service for maintaining order and curbing popular resistance ${ }^{3}$.

The growing concern with crime was a second trend in the history of policing. When discussion of crime in developing societies turned to Latin America, historians began to consider the available crime statistics and their producers, i.e., the police. Interest focused on the police because of their double function of controlling crime and of amassing crime data ${ }^{4}$. This approach had the advantage of calling attention to social phenomena ignored by traditional historians, such as criminal behaviour, and of raising new questions about the ways of understanding such behaviour. But, once again, the role of the police was taken as unproblematic: they were seen as producers of poor statistical material in response to concerns raised by the elites.

The concern about crime expanded into a broader view of social control, which became popular in the 1980s. Combined with Foucault's notion of the disciplinarian society, this view provided a framework for investigating the agents of social control

3 Referring to Brazil, resistance is the main concept in such analysis. Originating in the historiography of slavery, when some authors began considering anything the slaves did as an act of resistance against their masters, it spread to the general history of workers, unless they worked in the police. The conceptual counterpart of resistance is the unavoidable repression usually exercised not by the police but through the police by the ruling elites.

4 The use of criminal statistics for social history has an outstanding model in Gatrell (1980). For its use in Latin American history, the best example is Blackwelder and Johnson (1984). 
in Latin America, mainly the police and the prison system ${ }^{5}$. In these studies, the creation of institutions of social control became a central concern, hence questions raised about how the ruling elites built their agencies of control. This gave some space to the discussion of how to build an effective police system.

The myth of the controlling state (which emerged from the experience of autocratic military rule) obscured the problems faced by Latin American nation-states, during the nineteenth and early twentieth century, in building their police systems. For these states, finding workers willing to act as policemen in the streets, with poor pay and without any sort of training, was complicated. A large gap separated the projects and ideas of police administrators (contained in the official reports), and the reality of street patrolling or day-to-day investigation.

The reality of policing in early twentieth-century Rio de Janeiro was quite different from the discourse of so-called «scientific policing». To understand how the police worked and what sort of «effectiveness» they developed, it is necessary to look into their daily functioning. The study of cases involving women, especially those having to do with the control of «moral behaviour », may provide a useful instrument for analysing the practices of the police in early twentieth-century Rio. These cases offer two immediate advantages: they have been studied through other sources, mainly judicial records ${ }^{6}$, and they normally involve a plaintiff interested in the action of the police. A fact less frequently acknowledged about these cases is the important place they occupied among police duties.

The control of women represented a significant part of the elite efforts to control lower-class behaviour in late nineteenth-century Rio. Initiatives to limit the damaging consequences of prostitution were taken in almost every country - or at least were as fiercely discussed as in Brazil ${ }^{7}$. At this time, the role of women in modern society was a much-debated issue, generating demands for the education and protection of woman. Rio de Janeiro's elites followed the lead of European reformers. They tried to limit or end prostitution, and called for the reinforcement of women's familial role. This involved activities geared to the protection of poor women (such as the legislation on deflorations, which punished men for deceiving young women) as well as repressive measures (such as efforts to rid the streets of women at night).

Given the reality faced by Rio's women, the effectiveness of these policies was extremely limited. Poor women had a long-established place in the labour market. This meant that women needed to spend a significant part of their lives on the streets, and that they were exposed to the variability of labour markets ${ }^{8}$. Belonging to the working strata of society, many women suffered the same needs and experienced the same spatial mobility as working men. This was an advantage over the strict controls experienced by women in the wealthier groups. Women's position was also influenced by the changes introduced by mass immigration. The pool of young males isolated from their social backgrounds which filled the streets of Rio

s There are many studies analysing the police and the carceral institutions together. For Brazil see Adamo (1983), for Mexico Rolphe (1983), for Argentina Ruibal (1993), and for Costa Rica Palmer (1996).

6 See Esteves (1989), and Soihet (1989).

7 For the debates on regulation in nineteenth-century Brazil, see Engel (1989).

8 The role of street life for the poor woman in nineteenth-century Rio is described by Graham (1988). 
provided an ample choice for marriage or companionship, as well as sufficient customers for the widespread prostitution business.

Women appeared frequently in the daily police records. They appeared as offenders to public morality, suffering from a policy which sought to avoid their presence on the streets. Or they were brought under the protection of a paternalistic police institution, concerned with women's unprotected isolation in the male world of the streets. Frequently, this was an unrequested protection, extended in circumstances where it is difficult even to tell whether women were victims or offenders. They also appeared as victims - a position that is hardly statistically measurable -, exhibiting the marks of urban violence on their bodies or merely complaining of threats and injuries suffered. Finally, women appeared in police stations as prostitutes, neither victims nor offenders, but as part of an environment regarded by the police as very close to the criminal world, where policemen always played an important role.

Prostitutes deserve a special mention because, for the police, they were not embedded in the usual feminine duality of angel/demon or victim/offender. They were already beyond rescue, and were subjected to environmental measures of control which included tolerance and even some degree of good neighbourhood policy ${ }^{9}$.

To the policemen, mingling with women in their daily activities presented many kinds of problems. Not directly affected by modern criminology, as were those in the top echelons of the institution, patrolmen shared the more general view that women belonged to the familial sphere and, consequently, had to be guided through and protected from the realities of the streets. In women, policemen saw individuals who, deprived of social power, needed men to act on their behalf. The police were frequently called to play this role. But since policemen were also called, even more frequently, to discipline unruly women, they developed a greater consciousness of their power with respect to members of «the weak sex». Policemen could be cavalier and arbitrary in order to protect those women who played their traditional role as vulnerable and in need of assistance. But once they established that a woman was not playing (or enjoying) this role, they were liable to subject her to a much harsher treatment than they might apply to most of her male counterparts.

\section{a) WOMEN AS VICTIMS: SEXUAL OFFENCES}

The policing of sexual behaviour illustrates the role of both the police and citizens in the enforcement of laws and social values. The public of Rio - or at least part of it - was very helpful in denouncing immoral behaviour. Neighbours complained about nakedness, making it impossible for families to come to the windows, and denounced debauched women who received various and suspicious men ${ }^{10}$.

\footnotetext{
- It is very curious that prostitutes provided the model for the devil-woman, and falling into prostitution was the fate the police attempted to prevent, but when confronted with a prostitute, the horror of this condition seems to vanish. The danger was the fall, but thereafter the relationship was restructured in other terms, without the contempt used in «protection " of honest women.

10 A public employee saw the first floor of the house he lived in transformed into a brothel by a new tenant, Livro de Registro de Ocorrências, 12th DP, 03/02/25 (from now on, these books will be quoted only as Ocorrencias, with the station number and the date). The same complaint in Ocorrencias, 12th DP, 11/05/1921.
} 
Sexual offences were the main crimes associated with women as victims. When the Penal Code of 1890 created the crime of defloration - defined in its article 267 as «to deflower a woman of less than 21 , through seduction, deception or fraud [sedução, engano or fraude]» - it established one of the more important causes of trial in the early century. The defendant in these cases faced a jail sentence of between one and four years, unless he married the girl. The number of cases of defloration in police statistics remained close to 200 a year, and accounted for about $70 \%$ of the crimes against honour (immoral behaviour, rape, abduction and procuring were the others). Following a general increase in recorded crime, they increased in the second half of the 1920 s to an average of 400 a year.

The cases of defloration and abduction are some of the best illustrations of the action taken by the police following a complaint. An abduction usually involved an immediate danger of evil - the dreadful defloration -, and the police took steps to find the girl. In one case, the police reported that an agent had left town in search of the couple and, in at least three others, the girl was reported found. On the night of 7 February 1917, a cook came from her job in Gávea, a distant area of the city, to the 13 th District to complain about the abduction of her daughter, who worked as a servant. The police kept working on the case, and the abductor, a married barber of a police battalion, was arrested fifteen days later ${ }^{11}$. Another woman could not rest after she found that her daughter had run away with a man she met during Carnival ${ }^{12}$. After she informed the police, she started searching for the fifteen-year-old girl, until she received information that she had entered a rooming house with a man. Then, she got two civil guards and forced an entry. Against the objections of the manager, who denied the presence of any such couple, they found the man and the girl in their underwear. This allowed them to arrest the man in flagrante delicto, a situation rare in cases of defloration ${ }^{13}$.

An alliance to protect the integrity of young girls seemed to prevail. Relatives and police acted together in the surveillance of sexual behaviour. In cases of defloration, the mothers were the main sources of complaints, appearing in 36 cases, followed by fathers in 18 , and brothers in 6 . Rather than pointing to the exercise of a specific female authority in the couple, this prominent role of mothers reveals the absence of fathers. In a few cases, the mothers explained why they came instead of the father, and the brothers explained that they were replacing mothers unable to come.

In other cases, complaints came from employers, who were concerned about their domestic servants. A sense of responsibility grounded in traditional paternalistic relations, reinforced by the fact that many of these servants had been brought directly from the country (which encouraged masters to control the sexual behaviour of their servants), motivated these actions ${ }^{14}$. In addition, we cannot dismiss the fact

1 Ocorrências 17th DP, 17/01/1925, Ocorrências 13th DP, 08/02/1917.

12 Carnival frequently featured in defloration stories. Francisca de Paula presented her complaint at the military police barracks, because her seducer was a private. She told that the defloration happened during the Carnival festivities, but she could not be precise about the place, "only remembering that it was in some bushes in the area of this district ». Ocorrências, 19th DP, 24/3/1927. See also 5th DP, $15 / 2 / 1927$.

13 Ocorrências, 14th DP, 11/3/1918.

14 An employer reported the disappearance of a servant explaining « that he brought her from the country, being responsible for her, even though she was apparently, of age». Ocorrencias, 14th DP, $10 / 6 / 1923$. 
that overly liberal sexual behaviour by servants was perceived as a threat to moral values and, given the pervasive fear of venereal diseases, even the source of problems of hygiene. Of course not all employers behaved the same way. Some were accused of employing violence against their servants. Avilez Antonio da Rosa complained that his daughter, Dorides, was defiled by commander Alvaro Bastos, who forced her with death threats; the police ignored the complaint because she was over $21^{15}$.

An important point is how the girls reacted to this police interference in their lives and why, in some cases, they sought it. The first point to note is that in only eight cases did the victim freely decide to go to the police. In other two occasions, girls chose a complaint of defloration as a diversionary tactic when faced with charges of theft. Another girl took justice into her own hands and assaulted her deflowerer when she found him walking with another girl. The defloration complaint appeared after she was charged with assault. Certainly some girls looked for redress through a complaint to the police. One girl clearly presented a story that began with lascivious acts in the Rua Costa Bastos, and continued subsequently in the Guarany Cinema. After this, the man retracted his promise of marriage, and so she decided to complain ${ }^{16}$.

Only two cases had their origin in proactive policing: in one case an investigador found a girl in a suspicious house and brought her to the station, where she admitted the defloration ${ }^{17}$. The other case is more complex. It is useful to attempt to follow the comissário's report, although this is not always an easy task:

Agent 153 working in the railway station about 5 p.m. saw a young man and a girl talking. Zealous and helpful he approached and heard that the man was trying to convince her to accompany him. Suspicious, the agent followed them, taking a tram to the Largo do Estácio de Sá, where they got off, and the agent noticed that the girl was reluctant. At this moment, he presented himself and brought the couple to the station. Here we verified that the girl - Alzira Montalvão, 15, daughter of Aníbal Montalvão - is one of the girls who had run away from home at Rua São Carlos 21, according to the complaint registered at the 9th District. Alzira declared that, eager to find a job, she had agreed with her sister Maria to run away and had indeed left home. Somewhere they met a man who made their acquaintance and went for a walk with him. Later they went to his house, where he deflowered Alzira. Her sister Maria followed another man who showed up, whose name Alzira does not know, as she also does not know where Maria slept. The same agent 153 arrested, at Rua General Caldwell, Tomaz Brito da Cunha, who is the man who deflowered Alzira. He declared that he met Alzira at Praça 11 de Junho, walked with her and her sister and then they went home. At his door, he met a man who said he was a navy officer and that he came because he was called by Maria. Tomaz retired with Alzira, leaving them at the door, not knowing where they went. He adds that he had sexual relations with Alzira twice, but he does not think that he deflowered her due to the conditions of the act ${ }^{18}$.

15 Ocorrências, 12th DP, 17/03/1921.

16 Ocorrências, 12th DP, 07/04/1921. In this case, it is not clear whether the defloration occurred or only the lascivious acts.

17 Ocorrências 12th DP, 15/01/1925.

18 Ocorrências 14th DP, 14/02/1917. 
Young girls on the streets were viewed with suspicion and sometimes subjected to undesired protection. A civil guard brought two sisters to the station when he saw them with a group of men, «being known that they [the men] planned to carry the girls in a car to a distant place to practice perverse acts ». The girls had to be kept at the station because they refused to give their names and addresses ${ }^{19}$. The action of the police could be even more interfering with people's lives. After a civil guard informed the comissário of the entry of a young man and a girl into a suspicious house in Rua do Passeio, the comissário forced entry into the house and found a young law student dressing and a girl in her underwear hidden in the wardrobe ${ }^{20}$. The surveillance of such houses was part of the police's duties, and, in certain periods we can see that policemen were dedicated to prosecuting the managers of rooming houses who accepted unregistered couples on charges of procuring.

When the complaint was made by a relative, the girl still had some alternatives. She could comply with the denunciation or deny it. A refusal to name the accused or the suggestion of a different name - an old boyfriend, long dead - would make prosecution virtually impossible ${ }^{21}$. In many other cases, especially in abduction cases, charges seem to be part of a strategy to force marriage. On 31 March 1925, a military police private arrived at work in the 10th District confessing a defloration he had just committed ${ }^{22}$. He was probably willing to marry, as happened in six other cases recorded, some others noting only that the accused was ready to repair his mis$\operatorname{deed}^{23}$.

The police apparently shared the concerns of relatives about the moral behaviour of young girls. On the night of 28 November 1910, the comissario decided to keep Benjamim Portela in jail, following a complaint made by his fiancée's brother. Benjamim had picked up the girl at 7 p.m., only returning after 11 . The girl declared that he had not offended her, but the comissário thought it prudent to detain him until the delegado had a chance to talk with the girl's mother in his audience the following day $^{24}$. Sometimes, the concern was expressed against the will of the supposed victim. The police arrested a man when he went to ask for the clothes of his girlfriend, who apparently had moved in with him without her mother's consent or the legal bonds of marriage ${ }^{25}$.

19 Ocorrências 5th DP, 08/01/1925.

20 Ocorrências 5th DP, 23/01/1917. This case is not counted among the deflorations since there was no evidence of what happened in the medical examination. A few days later, the house was fined for failing to keep records.

21 Ocorrências 12th DP, 28/02/1917 has an unknown deflorer; Ocorrências 12th DP, 06/01/1917 has the name of a dead man given as the offender.

22 Ocorrências 12th DP, 31/03/1925. The use of defloration charges to achieve a marriage opposed by families is stressed by Corrêa (1994).

23 This does not imply that they got married. Esteves (1989) presents cases where the defendant agreed to marry and later changed his mind.

24 Ocorrências 15th DP, 28/1 1/1910. Cases of couples picked up by the police at late hours are quite fre. quent, reinforcing the idea of an unnofficial curfew for young women. Francisca Pereira da Silva, orphan, 18, servant at Travessa Cruz 14, was found walking with Gustavo Rodrigues Bizarro, Brazilian, pardo, 30, painter, at 2:30 a. m. He was arrested; she was questioned by the comissário, and explained that they did it more than once, having slept together on the Saturday before in a casa de tolerância [brothel] at Rua Senador Eusébio. She went on explaining that she was still a virgin «because Gustavo had not dishonoured her, having, however, practiced libidinous acts ». Ocorrências, 15th DP, 06/07/1913.

25 Ocorrências 19th DP, 25/05/1925. 
According to Martha Esteves, the Brazilian elites, through their criminal justice system, adopted two different strategies in dealing with a perceived deviation in woman's sexuality. They could either act punitively against the woman, reinforcing the deviancy, or opt for what Esteves calls the «civilising approach " (the sympathetic alliance of the police with those who wanted to punish the deflowerers or promote the marriage of the parties), which, in the case of deflowered girls, meant promoting marriage. What must be made clearer is the different weight given to each alternative by the law-enforcement agencies. We can see that juries were reluctant to co-operate with the civilising tendency shown by the judges, since most of the trials ended in verdicts of not guilty ${ }^{26}$. The police, on the contrary, appear in all cases as enforcers of the civilising approach. Since they were responsible for the first step in prosecution, they were bound to ask for the punishment of the defendant.

Police-station records confirm the option for the civilising approach. After having satisfied himself that the offended girls fulfilled the requirements of age and poverty ${ }^{27}$, the delegado wrote his order for an inquérito in 52 of the cases, and recorded the marriage in $\operatorname{six}^{28}$. When a friend came to the rescue of an alleged deflowerer, willing to declare that he also had had sexual relations with the girl, the delegado dismissed his statement as not important at this point of the procedure, it being of interest only to the courts ${ }^{29}$. The police could be useful in putting pressure on the accused to agree to a quick marriage. One accused came to the station declaring that he definitely would not marry the girl, having found her already defiled. He presented the marriage certificate five days 1 later $^{30}$. Deflorations were cases the delegado would not simply ignore.

\section{b) WOMEN AS VICTIMS: DOMESTIC VIOLENCE}

The ample sexual freedom which existed in Rio makes it very difficult to deal adequately with the subject of domestic violence. In most cases it is impossible within a household to determine whether we are dealing with long- or short-term relationships. Even married status might be of no practical consequence, as many couples were separated by migration or for other reasons. Whatever the circumstances, it is clear that violence against women in a relationship was an issue. The official statistics provide evidence of the significance of interpersonal violence in Rio and of the minor role played by women as violent offenders. But they cannot tell

26 Esteves (1989, p.108-109).

27 The procedures in cases of defloration were complicated by its position in a shady area between public and private prosecution. To enlist police help, the victim had to be proven incapable of hiring private counsel. They also had to prove that they were under 21 . The poverty clause was one of the main procedural complaints of defence lawyers, and the refusal of the proof of age was a useful device for obtaining jury acquittals. See Esteves (1989, p.92-94).

28 The plaintiffs usually went to the nearest police station, but procedures had to be carried out in the district where the defloration occurred. That is why so many cases had to be moved. In two of the cases, they had to be moved between two districts of the sample, but one did not reappear.

30 Ocorrências 19th DP, 04/09/1925. This delegado presents a remarkable record; in September and October of 1925, he received twelve complaints of defloration and records confessions and marriages in nine. One was sent to another district, one had an inquérito and one is not clear, with a note treating it wrongly as the same as the one tranferred to other district. 
us much about the part played by women as victims. In our sample (taken from police daily reports), women were involved in a large number of such cases, most of the time as victims (see table).

Number of Assaults and cases with women involved

\begin{tabular}{|lccc|}
\hline & 1909 & 1917 & 1925 \\
\hline assault cases $\ldots \ldots \ldots \ldots \ldots \ldots \ldots \ldots \ldots$ & 199 & 269 & 227 \\
involving women $\ldots \ldots \ldots \ldots \ldots \ldots \ldots \ldots$ & 41 & 93 & 84 \\
$\% \ldots \ldots \ldots \ldots \ldots \ldots \ldots \ldots \ldots \ldots \ldots$ & 20,6 & 34,6 & 37,0 \\
\hline
\end{tabular}

The cases where a relationship is clearly stated numbered only six in 1909 , but even in those, the character of the relationship is not clear. There is only one case of a husband accused of assaulting his wife, when the Italian Carlos Vairo was arrested, at request of his wife, whom he was accused of beating ${ }^{31}$. All other couples were described as lovers. These relationships might have been flimsy, as the one between military police sergeant, Manoel de Barros do Nascimento, and the prostitute, Maria Laudelina da Silva. After his arrest in her house, Manoel was sent to his barracks, but was left free by his fellow military policemen; he returned to her house armed with a razor, and had to be re-arrested ${ }^{32}$. Many cases do not show connection between offender and victim, but indicate that they shared the same address (some of these cases could involve love relationships, others might be disputes among neighbours in the cramped collective housing of Rio) ${ }^{33}$.

Other cases involved attempts by men to create relationships using coercion. One day, army soldier, Artur Nenem [Baby], gave three razor stripes to Maria Augusta de Jesus when she refused his invitation to go to a party. The next day, shop assistant, Zeferino Ferreira, a sixteen year old Portuguese youth, turned his attentions to the thirteen-year-old Dolores Maldonado; rebuffed, he punched her ${ }^{34}$. This is only a fraction of the cases that were in some way connected with relationships between the sexes. Disputes caused by men resenting approaches to their companions or members of their families are very difficult to count.

In cases involving couples, the police tolerated a considerable amount of violence, usually male violence. One explanation is that policemen were sympathetic to the predicament of men who had to deal with the misbehaviour of wives or partners. The best example probably is to be found in the following report made by comissário Eurico Brasil:

At 15:30, Mr. Alvaro de Moraes, resident at Rua Miguel de Paiva 179, Mr. Oswaldo Alves da Encarnação, resident at Rua da Concórdia 21, and Mr. Durvalino Alves da Encarnação, same address, came to this station and informed me that at Rua da Concórdia 66 a husband had tried to kill his wife who had betrayed him. Hildebrando Alves da Encarnação, Brazilian, white, married, 34, resident at

31 Ocorrências, 14th DP, 12/02/1909.

32 Ocorrências, 5th DP, 09/03/1909.

33 Many cases are clear disputes among neighbours or between landlords and tenants. See Ocorrências, 12th DP, 02/03/1917 and Ocorrências, 19th DP, 20/01/1925 and 23/03/1925.

${ }^{34}$ Ocorrências, 14th DP, 10/01/1909, and Ocorrencias, 15th DP, 11/01/1909. Both cases received small notices in the Jornal do Commércio. 
Rua da Concórdia 66 was the accused; Itália Gliosse da Encarnação, Brazilian, white, married, 28 , same address, was the victim. At 16:00, Hildebrando freely presented himself to me and told his story: for some time he had noticed with deep pain that his wife was not faithful, in spite of twelve years of marriage and their five sons. Working in a shop - the Silva Araújo-, it was not always possible for him to sneak back and watch her activities. A few times, he noticed the strange behaviour of Itália, who was always ready with an explanation. Time went by and the day before yesterday, coming home at night he caught his wife in the act of adultery. Carlos Ulrich, his neighbour at number 70 had become her lover, and it was him that Hildebrando found in Itália's bedroom. Ulrich took advantage of the painful surprise of Hildebrando to run out the back door, leaving however his hat and umbrella, objects that I showed to him in this station and which he agreed were his, confessing that he left them when he ran away. Hildebrando listened to the pleas of his sons and did not take violent revenge but left home, returning today to fetch the children. Itália, believing in Ulrich's promises, instead of receiving her outraged husband with humility, treated him harshly, starting an argument about the children. Hildebrando could not bear this anymore, got his gun from the bedside table and fired three times, hitting her once in the chest. Dazed, not knowing what he had done, trying not to make things worse, he stumbled out and came here to present himself....

The report is presented in a very sympathetic tone. The comissário suffers with the deceived husband and understands why he behaved violently - after trying to avoid such an ending. To the policeman, the husband's behaviour is fully comprehensible and calls for male solidarity appropriate to the circumstances. This was an example of proper behaviour, much more acceptable than those husbands who called the police to establish adultery.

The reluctance of the police to interfere may also be seen in cases where it was observed that the same male offender had assaulted the same woman before. João Batista do Espírito Santo was arrested twice - with a month interval - for assaulting his mistress. In spite of the inquérito resulting from an incident where he had hit her with a table fork on January 4, he was prepared to use a knife on her on February 3. As she was his mistress - and even less deserving because she was identified in the records as a prostitute - the police were not very interested in the case ${ }^{36}$. When Rosa Ferreira dos Santos complained that she had been beaten by her lover Arlindo Angelo Lopes, the comissário ended with the remark: «this man has assaulted his mistress many times and has already been arrested for this reason in the 16 th DP ${ }^{37}$.

The reluctance of the police to interfere might be explained in part by the widespread views of male authority, and partly because of police experience with victims (they usually withdrew their complaints). Prosecution could disrupt an arrangement which was either necessary in order to avoid poverty or desired because the lover had the means to provide for a better life. Waldemiro Ribeiro (white, 20, single,

35 Ocorrências, 13th DP, 06/11/1923.

36 This case is unusual because he wrote a long letter to the press to explain how he was driven to crime by her behaviour, working as a prostitute and taking another lover, a waiter who offered her gifts stolen from his restaurant, Jornal do Commércio, 10/2/1917 and Ocorrências, 13th DP, 04/01 and 03/02/1917.

37 Ocorrências, 19th DP, 14/01/1917. In 21 June 1923 an «old man »-aged 46 - attempted to kill his wife with a chisel. The comissário notes that it was the third time he had made an attempt on her life, but the delegado chose to ignore the case. Ocorrencias, DP, 21/6/1923. 
worker) was arrested by a policeman for beating Isaura Maria de Oliveira (parda, 27 , single, living with the offender) with a wooden stick. After her injuries were treated she came to the station to explain that she had hurt herself falling ${ }^{38}$. Maria Mercedes, black, 40, employed as a cook, was assaulted and hurt on the forehead, but refused to follow the policeman to the station. Others victims could not even be found for medical examination ${ }^{39}$.

That many policemen shared the general assumptions about male authority is apparent in the number of cases where the offenders were policemen. Just as Sergeant Nascimento, cited above, had the prostitute Maria Laudelina as his mistress, so did many others. Olívia Eliza da Silva went to the 12th DP to complain that she had been assaulted by the military police anspeçada number 697, João Lopes Ribeiro, and explained that they «lived as husband and wife ». A less well-established relationship was claimed by the cook, Francisca Luiza de Souza, beaten by her lover, the civil guard, João de Tal [de tal means she did not even know his surname $]^{40}$. Such cases seem to indicate that policemen shared a common view of male violence, which was probably made more prevalent by their daily acquaintance with violence at work. It may also suggest the hardship of life in the police forces, where salaries were low and relationships difficult to establish and to keep, provoking stress and brutal reactions.

The shooting dead of Livia Bellini Usiglio (17, white Brazilian, resident at Rua da Misericórdia 65) offers an example. She was murdered by her husband, military police sergeant Manoel Espiridião Abreu (26, black, Brazilian), who gave a military police barracks as his address ${ }^{41}$. In fact they were married and had lived together for less than three months when she returned to her father. She refused her husband's appeals to return to live with him. When he was on duty at Avenida Central during Carnival, he was taken aback when he saw her in a car with her sister and another man. He took her from the car and tore her costume while carrying her to her father's house. Three days later, when her father was out discussing the divorce with a lawyer, he entered the house and killed her ${ }^{42}$. We do not know the outcome of this case, but husbands who killed their wife were famous for receiving lenient treatment by the courts, usually acquitted on the grounds of temporary insanity.

We can notice a slight distinction in the police treatment of cases involving exlovers or abandoned husbands. Estranged wives or former lovers were able to enlist police help more easily; male rights seemed to diminish when the couple split up. Luiza Quintanilha registered a complaint of death threats against her former lover and got him arrested the next day for trying to force her to spend the night with him. The delegado ordered his prosecution for assault ${ }^{43}$.

The protection of abandoned wives was part of a general attitude towards lone women, who were viewed as easy prey, deserving the vigilant protection of society (women who had partners, it was believed, already had their protectors). It is signi-

Ocorrências, 14th DP, 03/03/1917.

Ocorrências, 19th DP, 05/01/1925. For victims not found see Ocorrências, 5th Dp, 02/01/1925 and $03 / 02 / 1925$.

Ocorrências, 12th DP, 02/03/1917, and Ocorrências, 13th DP, 17/01/1917.

Ocorrências, 5th DP, 22/02/1917.

Jornal do Commércio, 22/2/1917.

Ocorrências 12th DP, 03/09/1917. 
ficant how much of her social identity the woman lost through marriage. The police station was one of the places where she was not expected to appear; explanations were needed when she did so and she was commonly represented by a male. In one of the assault complaints, a husband reported that his wife had been assaulted by a neighbour, but her name is absent from the records ${ }^{44}$. The same might also happen when a woman was the aggressor, where she would be identified only as «the wife of " someone.

Values such as honour and decency can sometimes blur the distinction between offender and victim. Biazzina Siciliano, 33, Italian, married, was arrested after stabbing Francisco Santoro (25, Italian, single) to death. In the police records, it appears that she was constantly persecuted by Francisco with illicit proposals and threats. The same was reported by the Jornal do Commércio, which seems to have considered the case so justified and unimportant that it did not even report the death of Francisco. It is one of the few cases where we know the outcome: she was acquitted on the grounds that she was protecting her honour ${ }^{45}$. The universe of offenders was no different from the universe of the victims.

\section{c) THE FEMALE OFFENDER}

Biazzina Siciliano did not fit the common image of the female offender, but her crime in defending her honour brings into focus this essential issue in analysing the female offender. Crimes committed by women frequently involved the protection or loss of honour. If Biazzina protected her honour to the end, for Lucia Lucero, the "Bela Chilena», the loss of her honour began the downwards spiral that ended in murder. Her story appears very briefly in the records; she was arrested on the night of 11 February 1925, accused of attempted murder, after shooting her lover, the cab driver, José Antonio Infante Algarve. In a note in the margin, it is reported that he died the next morning. The newspapers provide further details about the murderess; it was rumoured that, in her native Chile, she had married a lyric singer against the wishes of her family and had lived with him until he abandoned her in Rio, where «she gave herself up to an adventurous life, until she fell so low as to become the mistress of a cab driver ", ending by killing him with three shots in her boudoir ${ }^{46}$.

Lucero and Siciliano were extreme cases of female criminality; most of the time reality was much more petty. The female offender, statistically only a small part of the world of offenders, was basically a misdemeanant. Presenting a woman as a vagrant was somewhat contradictory to the prevalent ideology, in which women were not supposed to work outside the home; but the authorities were constantly concerned with the presence of women in the streets, and the police would act on any breach of proper behaviour. This explains the high number of arrests on charges of drunken and disorderly conduct rather than vagrancy, and also permits an understanding of why some women were targeted as undesirable and became the victims of constant arrests on such minor charges.

44 Ocorrências, 15 th DP, 02/02/1909.

45 Ocorrências, 5th DP, 30/01/1917. The result of the trial is reported by Rachel Soihet (1989, p. 305 . 306 ), who found the trial records in the Tribunal do Juri. The acquittal was confirmed by a superior court on 17 January 1920.

46

Ocorrências, 12th DP, 12/02/1925 and Jornal do Commércio, 13/02/1925. 
It is not simple to establish the identity of these women. They probably were often imprecise in giving name and/or possible address, if the police cared at all to listen to them while making their notes ${ }^{47}$. But certainly the statistics of arrests grew with women such as Sebastiana Rosa (black, 21 or 22 years old, depending on the record), arrested on 29 January 1909 on a charge of vagrancy; then on 17 February for drunkenness, and again on the 20th for disorderly conduct, a charge that was repeated on 16 March. The address is the same in the second and fourth charges, which enables us to be quite sure that the police were dealing with the same person; but on the third charge there is no address at all.

The campaign against vagrancy, and especially vagrant women on the streets was extremely fierce in the 5th DP during August and September 1913. We find many women arrested time and time again, and can make some connections which point to the permanence in the streets of some of those women. A good example is Henriqueta Gomes de Carvalho, a name unusual enough to lead us to believe it is the same person in each case. Her first arrest was on charges of drunkenness, on 25 August. She had a job as a cook, and an address in one of the rooming houses of Travessa do Paço. When she was caught drunk again, three days later, she was recorded as without job or residence. We can only guess at what became so unbearable - or was it only the result of drunkenness - to Henriqueta that she used a cigarette to set her clothes on fire during the night. This did not make any difference to her future, however, because she returned on the 12th and the 17th of September to the same cell, and appeared again on the same charge four years later ${ }^{48}$.

The list of these women, mostly young, non-white and single, could be very extensive. They certainly could provide a busy day for the comissários, especially in the early years of the century, when the repression of vagrancy was harsher. This continuous association established a relationship that looks rather bureaucratic and from which concerns about personal condition were absent, but, at the same time, the identification of these women was done on a personal basis, meaning that the comissários knew who were the habitual vagrants in their neighbourhoods. To a certain extent, the police might provide some sort of shelter for many of those vagrants when nothing else was available, the attitude of the comissários went that far in helping vagrants. However, this sort of female offender soon would not represent any threat to society, becoming instead merely a disturbance to the peaceful night's sleep of the police station. In the same way that too much contact dissolved the femininity of the common female offender from the point of view of the police, so it did with prostitutes.

47 We can be reasonably certain of an individual under arrest being the same person when the address was the same, or when age and colour agreed. Filiation, although usually recorded, was not useful due to the majority of unknown. The difficulty may be illustrated by the vagrancy arrest of 13/03/1909 that brought in two Benedita Maria da Conceição, or did the comissário recorded the same woman twice?

48 Ocorrências, 5th DP, 25 and 28/8/1913; 12 and 17/9/1913, and 20/1/1917. Another problem of the records is that, in the fourth charge, she was reduced to Henriqueta Gomes. Probably the comissário was too busy to care about the complete sumame of a vagrant; this is not the only case where this happens. 


\section{d) POLICING PROSTITUTION}

As Rio confirmed its position as the country's cultural and political capital, during the second half of the nineteenth century, the subject of prostitution became increasingly important. Though much was blamed on the evils of prostitution, there was at the same time a certain agreement about its necessity, given the large number of young males in the city. By the end of the nineteenth century, Rio joined Buenos Aires as the end of the line of what was considered a profitable market in white slavery, recruited mainly in the impoverished, Jewish areas of central Europe ${ }^{49}$. It could be said that, by the early twentieth century, prostitution in Rio was divided into three main groups: a high-class prostitution, the middle group known as polacas (the Eastern European women) and the poorest, and cheapest, black or pardo prostitution.

Although the state was not involved directly in the control of prostitution - only pimping was considered a crime -, the police were always in contact with the prostitutes, exercising some informal control. We can see from the press that complains about widespread prostitution in the city centre were frequent, and that the police were expected to restrain prostitutes' behaviour. There was tacit approval when policemen acted to prevent prostitutes from walking the streets, or when they tried to force them off the main thoroughfares. When, in the 1890s, the police began to arrest every prostitute walking the Rua Senador Dantas, the lawyer, Evaristo de Moraes, obtained a writ of habeas corpus to extend to prostitutes the freedom of circulation guaranteed every other citizen by the constitution ${ }^{50}$. The law that reorganised the police in 1907 contained a proviso calling for the special repression of «scandalous prostitution». This general climate among the elites set the tone for historians to point to an active, repressive police attitude towards prostitution, although this was probably not common.

In fact, the police contact with prostitution was too close and constant to be purely repressive. A much more complicated relationship developed between policemen and prostitutes, who had to work out some form of coexistence. One obvious point is that policemen, who were part of the world of young males that characterised the city, were customers to prostitutes. The prontidão of the 12th DP was arrested while having sex with a jailed prostitute ${ }^{51}$. Moreover, the areas where prostitution was concentrated attracted disorderly groups (criminals as well as sailors and soldiers), which were the targets of police control. This concentration was important to prostitutes, who were frequently victimised by men. Though our sample of police records is not particularly useful for homicide cases, it is significant that two of the six cases which are described from the beginning as homicide involved murdered prostitutes. On 16 March 1917, the 5th DP was called to Rua das Marrecas 39, where the comissário found:

on the bed covered with blood was the prostitute Augusta Martins, Portuguese, parents unknown, white, 24 , single, presenting two cuts in the neck, one of them

On white slavery, from the European perspective, see Bristow (1982, especially chapter 4). An account from Brazilian sources can be found in Rago (1991), and Menezes (1992).

Evaristo de Moraes (1897) himself tells the story of the legal battle. Such extra-legal behaviour affected pimps, too, who were arrested, and were released only after presenting boat tickets to another country. 
very deep [...] After the corpse was photographed and the doctors made the examination, it was established by a search of the premises that the reason for the beheading [sic.] was theft [there follows a list of stolen jewellery].

The case is not very different from that reported by the comissário of the 12 th DP on 18 January 1925 :

Mr. Jacinto Antonio Vieira, employee in the rooming house at Rua dos Arcos 814 came to this station to report that Fanny Mayertall, Polish, 42, married, tenant of the front room was found dead. Going to the property I found the door of the said room open and entering I found that indeed the said Fanny lay dead over the bed, completely naked, lying on her back, with the arms crossed over the chest and tied with the sort of line used in fishing. On the neck we found visible signs of strangling, her mouth being tied with the same line as the wrists. The room did not show evidence of a fight, only the bed... ${ }^{52}$

Such cases were exceptional because they presented the very unusual situation of unknown perpetrators. The press followed such cases for some time. The figure of the ageing Polish prostitute, described as well to do, having a savings account and jewels, besides having received some lottery money two days before the murder, appealed to the public imagination. Details abounded in the press for the next few days: they told of her marriage in 1920 to a mysterious villain known as Perroquet, who disappeared with a large sum of her money. They told how, afterwards, she became the mistress of a Portuguese man. After the murder, her property included two houses, jewels (which were not stolen after all, countering the initial idea of robbery) and $10.000 \$ 000$ (ten thousand mil réis) in savings ${ }^{53}$.

These were extreme cases, but they demonstrate the real threat to prostitutes from their working conditions, alienated from accepted society. From the point of view of the prostitutes, the police were something to be avoided whenever possible, but which they needed when victimised. There were circumstances when prostitutes clearly tried to avoid contact with the police. The prostitute, Alice Le Bihar, went to the station to complain about a forged note only because it was the second time the same man had used counterfeits; she explained that, on the first occasion, she had preferred to destroy the bill «to avoid troubles with the police ${ }^{54}$.

Frequently, the police were called in to arbitrate disputes between prostitutes and customers. The arguments generally centred around money: Dirceu Dantas Duarte had sex with the prostitute, Prazeres dos Santos, and refused to pay, threatening her with a knife. The comissário reprimanded him for his incorrect behaviour, but Dirceu reacted with a torrent of insults, accusing the comissário of being a «shameless pimp». The comissário responded by prosecuting Dirceu for contempt ${ }^{55}$. Pros-

52 Ocorrências, 5th DP, 16/3/1917 and Ocorrências, 12th DP, 18/1/1925.

s3 After a week, the story disappeared from the pages of the Jornal do Commércio. The evidence of fortune presented by some prostitutes is quite surprising; on 24 May 1923, the prostitute Paulina Sacman or Paulina Gennen died suddenly in her house, Rua Joaquim Silva 3. She was Russian, widowed, 39 years of age. She owned five houses in the same street, where six other prostitutes lived, and had a small fortune in currency and savings listed in Ocorrências, 13th DP, 24/5/1923.

55 Ocorrências, 5th DP, 2/11/1922. Accusations against policemen of protecting prostitutes appear now and then. Ocorrencias, 13th DP, 26/9/1912 shows a man accusing the comissário of not helping a laundress who was not being paid by prostitutes. 
titutes were also the target for petty thieves, who found it easy to gain access to their rooms ${ }^{56}$. Such disputes involving sex and money could end in fights, and in red-light districts such fights would attract a lot of people. All this forced the police to keep red-light districts under close surveillance, but without exerting the kind of pressure that would provoke conflict. Even policemen might disagree and argue, as when some policemen were escorting the prostitutes, Francina Knicht, Angelita Tuar and Mariette Guvai, to the station when they complained the loss of a bracelet. It provoked a fight between military policemen and civil guards, because a military policeman accused the guards of stealing the bracelet ${ }^{77}$.

While, in general, the police showed a very paternalistic and authoritarian attitude towards prostitutes, the behaviour in each circumstance could vary widely. More frequent troublemakers sometimes appeared among the prostitutes, and they would soon be identified by the policemen. Comissário Paulo Filho had two encounters with Josefa Constancia Bonfim, known as Cow's Eye [Olho de vaca]; in the first, he was policing the area and arrested her for assault with a razor; less than two months later, he was on duty at the station when she was brought in for «being dressed immorally in front of her house ». He promptly marked her as a troublema$\mathrm{ker}^{58}$. Disorderly conduct probably helped the police - if help they needed - to justify a certain harassment of prostitutes, in which they found support from society. When cases involved prostitutes, the police enjoyed a freedom of movement that they would not find elsewhere; the prostitute known as Lola was carried to the station accused of swearing and threatening another prostitute. She behaved disruptively in the station, and was held for a few hours, «even being put in jail for a time $»^{59}$. When they received a report that an accused deflowerer was sleeping with a prostitute, they promptly rushed her room only to find that he was not there and to receive her furious invectives. She was arrested for disorderly conduct ${ }^{60}$.

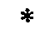

* * *

Women composed a part of society that had no acknowledged power, but which was deserving of protection. To be sure, this protection was exercised under certain conditions, which most of the women were unprepared for or incapable of accepting. That thrust them into the universe of the police station, where policemen were made the prime judges of the merits of women seeking help. The image of the respectful woman became too banal after frequent contacts with vagrants and prostitutes, and the police found that, in most of the cases, they could exercise an authority over these women which most groups in society were able somehow to avoid.

36 Heitor Guimarães, Brazilian, 24, single, without occupation, was arrested in the bedroom of Ema Lalianne, at Beco Teotonio Regadas 18, for stealing a pair of earrings. In other cases, men had spent the night with prostitutes, only to wake up with their valuables missing. Armando Duarte complained that he had his wallet with $560 \$ 000$ (five hundred and sixty mil réis) stolen by the prostitute, Anna Martins, at Rua Joaquim Silva 84. Ocorrências, 13th DP, 12 and 19/1/1917.

Ocorrências, 13th DP, 5/4/1915.

She was parda, 24, single, prostitute, resident at Rua dos Arcos 51 . In the second case, she was prosecuted as a vagrant. Ocorrências, 12th DP, 3/2/1921 and 31/3/1921.

Ocorrencias, 13th DP, 18/2/1915.

Ocorrências, 13th DP, 24/7/1923. 
This disregard for the social value conferred on women was absent when families or the women themselves came to claim protection for their honour. In this case, the usual abuse of authority which faced women daily was turned against the seducer, who was now seen as underserving of the safeguards provided by the laws.

\author{
Marcos L. Bretas \\ Departamento de História \\ Instituto de Filosofia e Ciêncas Sociais \\ Universidada federal do Rio de Janeiro \\ Largo de Sao Francisco 1 \\ 20051-070 Rio de Janeiro 6RJ \\ Brasil \\ E-mail: bretas@ifcs.ufrj.br
}

\title{
REFERENCES
}

Adamo, S., The Broken Promise. Race, Health, and Justice in Rio de Janeiro, 1890-1940. Doctoral diss., University of New Mexico, 1983.

Blackwelder, J. K., Johnson, L., Estadistica policial y accion policial en Buenos Aires, 18871914, Desarrollo Economico, 1984, 93, 24.

Bristow, E., Prostitution and Prejudice. The Jewish Fight against White Slavery 1870-1939, Oxford, 1982.

Câmara, H., Marechal José Pessoa. A força de um ideal, Rio de Janeiro, 1985.

Corrêa, R. L., A Questão da Cor no Feminino. Pretas, pardas e brancas nos inquéritos policiais nas freguesias de São Cristóvão e Espírito Santo, MA diss., IFCS, UFRJ, 1994.

Engel, M., Meretrizes e Doutores. Saber Médico e Prostituição no Rio de Janeiro (1840. 1890), São Paulo, 1989.

Esteves, M., Meninas Perdidas: Os populares e o cotidiano do amor no Rio de Janeiro da Belle Epoque, Rio de Janeiro, 1989.

Gatrell, V. A. C., The decline of theft and violence in victorian and edwardian England and Wales, in Gatrell, V. A. C., Lenman, B., Parker, G, (eds), Crime and the Law: The Social History of Crime in Western Europe since 1500, London, 1980.

Graham, S., House and Street: The Domestic World of Servants and Masters in NineteenthCentury Rio de Janeiro, Cambridge, 1988.

Menezes, L. M., Os Estrangeiros e o Comércio do Prazer nas Ruas do Rio (1890-1930), Rio de Janeiro, 1992.

Moraes, E. de, A Questão das Prostitutas, Rio de Janeiro, 1897.

Palmer, S., Confinement, policing, and the emergence of social policy in Costa Rica, 18801935, in Salvatore, R., Aguirre, C. (eds), The Birth of the Penitentiary in Latin America: Essays on Criminology, Prison Reform, and Social Control, 1830-1940, Austin, 1996, p. 224-253.

Rago, M., Os Prazeres da Noite: Prostituição e códigos da sexualidade feminina em São Paulo (1890-1930), Rio de Janeiro, 1991.

Rolphe, L., Police and Penal Correction in Mexico City, 1876-1911: A Study of Order and Progress in Porfirian Mexico, Doctoral diss., Tulane University, 1983.

Ruibal, B. C., Ideología del Control Social. Buenos Aires 1880-1920, Buenos Aires, 1993.

Soihet, R., Condiçāo Feminina e Formas de Violência: Mulheres Pobres e Ordem Urbana 1890-1920, Rio de Janeiro, 1989. 